\title{
ПІДХІД НА ОСНОВІ АКТУАРНИХ МАТЕМАТИЧНИХ МОДЕЛЕЙ ДО ЗАДАЧ СТРАХОВОÏ МЕДИЦИНИ
}

\author{
В. П. Марценюк, Н. Я. Климук, І. Є. Андрущак \\ Тернопільський \\ державний \\ медичний \\ університет \\ імені \\ І.Горбачевського
}

У роботі розвинуто підхід на основі актуарних математичних моделей до задач медичного страхування. Моделі сформульовано в термінах рівнянь Колмогорова та Тіле.

Ключові слова: медичне страхування, рівняння Колмогорова, рівняння Тіле

\section{ПОДХОД НА ОСНОВЕ АКТУАРНЫХ МАТЕМАТИЧЕСКИХ МОДЕЛЕЙ К ЗАДАЧАМ СТРАХОВОЙ МЕДИЦИНЫ}

\author{
В. П. Марценюк, Н. Я. Климук, И. Е. Андрущак \\ Тернопольский \\ государственный \\ медицинский \\ университет \\ имени \\ и. \\ Я. \\ Горбачевского \\ В работе развит подход на основе актуарних математических моделей к задачам медицинского страхования. \\ Модели сорормулированы в терминах уравнений Колмогорова и Тиле.
}

Ключевые слова: медицинское страхование, уравнение Колмогорова, уравнение Тиле

\section{APPROACH BASED ON ACTUARIAL MATHEMATICAL MODELS FOR THE PROBLEMS OF HEALTH INSURANCE}

\author{
V. P. Martsenyuk, N. Ya. Klymuk, I. Ye. Andrushchak \\ Ternopil State Medical University by I.Ya. Horbachevsky
}

\begin{abstract}
In this work there is developed an approach based on actuarial mathematical models for the problems of health insurance. Models are presented in terms of Kolmogorov and Thiele equations.
\end{abstract}

Key words: health insurance, Kolmogorov equation, Thiele equation

Вступ. Охорона здоров'я населення України є пріоритетним напрямком соціальної політики держави. Національна програма реформування галузі передбачає модернізацію системи охорони здоров'я і встановлює основні концептуальні пріоритети розвитку медичної галузі країни. Значиме місце у вирішенні проблем національної охорони здоров'я в багатьох країнах світу посідає медичне страхування [1-4]. При цьому одним з основних способів подолання проблем у національних системах охорони здоров'я $€$ використання можливостей медичного страхування 3 метою підвищення якості медичної допомоги й збереження здоров'я населення.

У рамках розв'язання завдань, передбачених національними проектами, особливого значення набувають науково-практичні дослідження з удосконален ня фінансового забезпечення охорони здоров'я. Про- блеми функціонування системи медичного страхування активно обговорюються на різних рівнях. Сьогодні потрібно переходити від обговорення напрямків удосконалювання до фази інтенсивного впровадження раціональних організаційно-фінансових рішень в області медичного страхування.

Наукові підходи, вироблені в працях по теорії фінансів і страхової справи [1-5], послужили базою для розробки теоретико-методологічних основ сучасного медичного страхування. Разом з тим, інтенсифікація сучасного економічного й соціального розвитку вимагає розширення й поглиблення наукових, методологічних і практичних досліджень в області медичного страхування.

Метою роботи $є$ розвиток теоретико-методологічної бази медичного страхування шляхом розробки актуарних математичних моделей.

() В. П. Марценюк, Н. Я. Климук, І. Є. Андрущак 


\section{Матеріали та методи дослідження}

Наша модель грунтується на припущенні про те, що час, через який клієнт страхової компанії захворіє на хворобу (яка підлягає медичному страхуванню), якщо його вік становить $x, \epsilon$ випадковою величиною $T_{x} 3$ неперервним розподілом. Такий розподіл буде повністю описаний, якщо ми знатимемо:

- функцію неперервного розподілу $F_{x}(t)=P\left\{T_{x} \leq t\right\}$, або

- відповідну функцію щільності $f_{x}(t)$ або

- силу захворюваності $\mu_{x, t}$ Даний показник введено по аналогії з демографією. Сила захворюваності $\epsilon$ швидкістю ймовірності захворіти у віці г для особи, яка зараз має вік $x$. Вона може бути обчислена як:

$\mu_{x, t}=-\frac{d}{d t} \ln S_{x}(t)$. Тут $S_{x}(t)=1-F_{x}(t)$ - функція опірності до хвороби (тобто ймовірність не захворіти до віку г для особи, яка зараз має вік х).

Один із підходів полягає в припущенні, що є відомою функція неперервного розподілу $E_{x}(t)$ (мається на увазі, що вона була оцінена, використовуючи відповідні статистичні дані). Це можна зробити на основі таблиці захворюваності I (тут I - ймовірність захворіти у віці х років), яку можна використати для обчислення оцінок параметрів страхового полісу (ОПП).

Припустимо, що нам відомо силу захворюваності у кожному віці. Зобразимо це схематично:

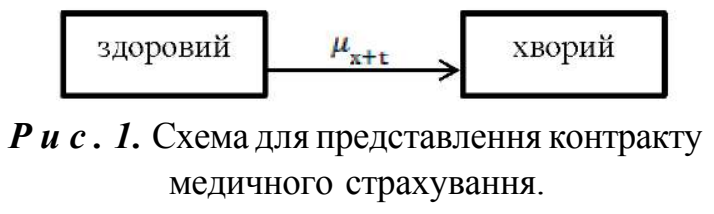

Задачу медичного страхування можна сформулювати таким чином. При відомій силі захворювання для кожного віку $\mathrm{T}_{\mathrm{xr}}$ потрібно знайти всі ймовірності і ОПП, які потрібні для знаходження страхової суми та преміі, визначених в страховому полісі.

Пропонований підхід полягає у вирішенні звичайного диференціального рівняння Колмогорова для знаходження ймовірності «не захворіти»:

$$
\frac{d}{d t}{ }_{t} p_{x}=-{ }_{t} p_{x} \mu_{x+t}
$$

Тут і надалі в роботі використовуватимуться позначення актуарної математики $\rho_{t}=S_{x}(t)$. В якості початкового стану розглядаємо $0_{0} p_{x}=1$. Задача полягає у відшуканні $\rho_{x}$ для всіх $t>0$.
Для обчислення резервного капіталу з часом $V(t)$ що $є$ визначальним при укладанні контракту медичного страхування, пропонується використовувати рівняння Тіле:

$$
\frac{d}{d t} V(t)=V(t) \delta+\overline{P_{x}}-\mu_{x, t}(1-V(t)) .
$$

Тут $\bar{P}_{x}$ - розмір страхової премії. Рівняння Тіле дозволяє обчислити нам вартість страхового полісу а також ОПП будь-яких грошових операцій. Граничною умовою у цьому випадку є кінцева умова швидше ніж початкова.

Дуже рідко $\mu_{x, t}$ має настільки просту форму (наприклад константа), що ми можемо знайти розв'язки в явному вигляді. У той же час майже завжди розв'язки можуть бути знайдені чисельно. Ми зробимо це використовуючи найпростіший метод - схему Ейлера.

\section{Результати та їх обговореня}

3 першого погляду підхід на основі рівнянь Колмогорова та Тіле здається більш складним, ніж просте використання таблиці захворюваності. Це дійсно так, хоча на сьогодні, завдяки потужним обчислювальним комп'ютерним методам, він є цілком реальним.

Переваги такого підходу проявляються при розгляді більш складних контрактів. Так, на рис. 2 наведено модель, яка лежить в основі медичного страхування на випадок втрати працездатності 3 метою заміщення втрачених заробітків.

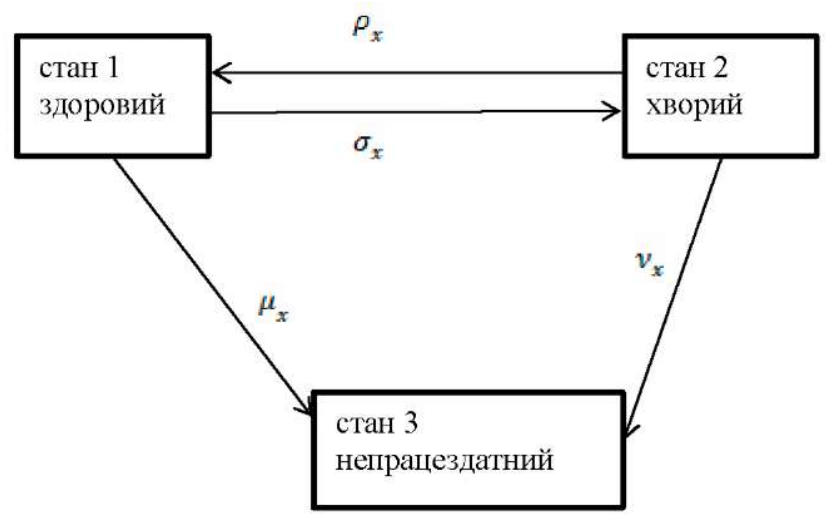

$\boldsymbol{P} \boldsymbol{u} \boldsymbol{c} 2$. Модель, яку можна використати для представлення контракту страхування на випадок непрацездатності.

Ми могли б сформулювати цю модель в умовах випадкового часу, коли відбуваються події, аналоги випадкового часу захворіти Т Це надзвичайно складно і обчислення ймовірності і ОПП за допомогою цього підходу є неперспективним. 
Але, якщо ми припустимо, що відомо «сили», що керують переходами між трьома станами, аналоги до сили захворювання $\mu_{x, t}$, то легко можна записа-

$$
\begin{gathered}
{ }_{h} p_{x} \approx{ }_{0} p_{x}+\left.h \frac{d}{d t}{ }_{t} p_{x}\right|_{t=0}={ }_{0} p_{x}+h\left[-{ }_{0} p_{x} \mu_{x+0}\right]=1-h \mu_{x} \\
{ }_{2 h} p_{x} \approx{ }_{h} p_{x}+\left.h \frac{d}{d t} p_{t}\right|_{t=h}={ }_{h} p_{x}+h\left[-{ }_{h} p_{x} \mu_{x+h}\right]=1-h \mu_{x}-h\left(1-h \mu_{x}\right) \mu_{x+h} \\
{ }_{3 h} p_{x} \approx{ }_{2 h} p_{x}+\left.h \frac{d}{d t} p_{x}\right|_{t=2 h}={ }_{2 h} p_{x}+h\left[-{ }_{2 h} p_{x} \mu_{x+2 h}\right]
\end{gathered}
$$

I так далі. Такі обчислення легко можна програмувати в будь-якому із наступних програмних засобів: електронні таблиці; мови програмування (наприклад, Java); стандартні математичні пакети (наприклад, Maple, Matlab, Mathematica).

Зауважимо, що схема Ейлера $є$ найпростішим обчислювальним методом для вирішення диференціального рівняння. Однак, це один з найповільніших і найменш точних методів. Тому на практиці доцільно використовувати більш ефективні чисельні методи.

Розв'язання диференціального рівняння Тіле. Ми можемо розв'язати диференціальне рівняння Тіле двома способами. ти аналоги рівняння Колмогорова і рівняння Тіле $\mathrm{i}$ потім розв'язати їх чисельно.

Розв'язок рівняння Колмогорова. Застосувавши метод Ейлера до рівняння Колмогорова ми отримуємо:

1. Вперед від початкової умови:

$$
V(0)=0
$$

\section{2. Назад від кінцевої умови:}

$$
V(\mathbf{n})=0 \text { або } V(0)=1
$$

При розв'язуванні рівняння Тіле початкове значення дуже часто є невідомим. У той же час ми майже завжди знаємо кінцеве значення. Тому ми розв'яжемо рівняння Тіле починаючи від кінцевої умови. Застосувавши метод Ейлера з розміром кроку $к$ ми маємо:

$$
\begin{gathered}
V(n-h) \approx V(n)-\left.h \frac{d}{d t} V(t)\right|_{t=n}=V(n)-h\left[V(n) \delta+\bar{P}-\mu_{x+n}(1-V(n))\right] \\
V(n-2 h) \approx V(n-h)-\left.h \frac{d}{d t} V(t)\right|_{t=n-h}=V(n-h)-h[V(n-h) \delta+ \\
\left.\bar{P}-\mu_{x+n-h}(1-V(n-h))\right] \\
V(n-3 h) \approx V(n-2 h)-\left.h \frac{d}{d t} V(t)\right|_{t=n-2 h}=V(n-2 h)-h[V(n-2 h) \delta+ \\
\left.\bar{P}-\mu_{x+n-2 h}(1-V(n-2 h))\right]
\end{gathered}
$$

Висновки. 1. В роботі запропоновано актуальний підхід до побудови математичних моделей, які можуть бути використані при розробці полісів медичного страхування.

2. За допомогою рівняння Колмогорова, знаючи силу захворюваності можна здійснювати розрахунок залеж-

\section{Література}

1. Кудрявцев А. А. Страхование здоровья: опыт Великобритании А. А. Кудрявцев, Р. Г. Плам, Г В. Чернова - М. : Анкил, 2003. - $216 \mathrm{c}$.

2. Система страхования в здравоохранении : учеб.-метод. пособие / Ю. П. Лисицын и др. - М. : Федер. фонд ОМС, 2001.- $223 \mathrm{c}$.

3. Азаматов Д.М. Страховая медицина. Социально-фило- них від часу ймовірностей клієнта страхової компанії не захворіти на захворювання, що розглядається.

3. За допомогою рівняння Тіле пропонується розраховувати залежний від часу резервний капітал, що $\epsilon$ визначальним при укладанні договору медичного страхування. 